Ribogospod. nauka Ukr., 2017; 4(42): 99-111

DOI: $10.15407 /$ fsu2017.04.099

UDC 597-1.05:[597.583.1:597.554.3]:628.394.1

\title{
PHYSIOLOGICAL-BIOCHEMICAL STATUS OF PERCH (PERCA FLUVIATILIS LINNAEUS, 1758) AND ROACH (RUTILUS RUTILUS LINNAEUS, 1758) IN CONDITIONS OF EXCESSIVE ANTHROPOGENIC PRESSURE ON THE BODY OF WATER
}

V. Martseniuk,wmarzenuk@gmail.com, Institute of hydrobiology of Ukrainian National Academy of Sciences, Kyiv

A. Potrokhov, alport@bigmir.net, Institute of hydrobiology of Ukrainian National Academy of Sciences, Kyiv

O. Zinkovskyi, hydrobiol@igb.ibc.com.ua, Institute of hydrobiology of Ukrainian National Academy of Sciences, Kyiv

M. Prichepa, prichepa1987@ukr.net, Institute of hydrobiology of Ukrainian National Academy of Sciences, Kyiv

Purpose. To establish during the spring and summer period the physiologically-biochemical response of fish to the effect of excessive anthropogenic contamination on the indicators of the maintenance of hormones and glucose in their blood plasma, and the possibility of using these indicators to assess the ecological status of the water body.

Methodology. Two Lakes in the city of Kyiv were selected for research, which are characterized by various hydrochemical and toxicological indices. These water objects were Lake Kyrylivske (Opechen Upper) - a water body from the system of Lakes Opechen (polluted by the water body) and Lake Babyne that is on Trukhanov Island (relatively clean Lake, control). Fishing was carried out in the early spring and in the middle of the summer by hook fishing gear. In laboratory conditions, the total content of thyroxine (T4), triiodothyronine (T3) and cortisol in blood plasma of fish was determined by enzyme immunoassay, using commercial T3-EIA, T4-EIA sets (NPL Granum, Ukraine) and DS-EIASteroid-Cortisol ("Diagnostic Systems" NGO, Russia) using the Rayto RT-2100C EIA Analyzer. The glucose content was determined by spectrophotometrically glucose oxidase method using standard commercial kits "Filisit-Diagnostika" (Ukraine).

Statistical data was processed using the programs Statistica 10.0 and Excel programs from the Microsoft Office suite.

Findings. In the spring, excessive anthropogenic pressure on the Lake Kyrylivske causes an energy imbalance in fish, which causes the deceleration of catabolic reactions in their tissues. In this period, the perch and roach react to the conditions of existence in the Lake Kyrylivske increase in the content of cortisol in the blood compared with fish from the Lake. Babyne, what can be their reaction to excessive anthropogenic stress.

Also, during this period, the low content of thyroxin and triiodothyronine in the perch from the Lake Kyrylivske was noted compared with the Lake. Babyne, which is probably caused by changes in the oxygen and temperature regime during spawning.

Increase of thyroxine content in roach from Lake Kyrylivske during the summer period with respect to fish from the Lake Babyne may indicate an increase in the negative effects of toxic substances on the physiological state of fish as water temperature rises. At the perch from the Lake Kyrylivske content of T3 and T4 in 1.19 and 6.22 times, respectively is higher, than that of fish from the Lake Babyne, which is associated with enhanced processes of generating energy in his body, as a result of increased activity of redox reactions, as well as different degrees of oxygen consumption by tissues under complicated conditions of existence.

In the summer, in the roach from the Lake Babyne content of cortisol is 2.05 times higher than

CV. Martseniuk, A. Potrokhov, O. Zinkovskyi, M.Prichepa, 2017 
that of roach of Lake Kyrylivske, which may be the result of a violation of the mobilization of energy compounds by the organism of this species from the Lake Kyrylivske The content of glucose in the blood plasma of the perch from the Lake Kyrylivske was $10.5 \mathrm{mmol} / \mathrm{L}$ in the summer, which is 1.43 times higher than that of fish from the Lake Babyne. Such a buildup of glucose can be a mechanism for counteracting toxic substances in the environment. Decrease of glucose content in roach from Lake Kyrylivske is probably the consequence of increased its utilization to ensure the energy homeostasis of the organism under similar conditions of existence.

Originality. Inter-species and inter-season differences in the content of hormones in perch and roach, which were under the influence of anthropogenic loading on the water bodies of the metropolis, were established.

Practical Value. The obtained results suggest that the characteristics of the thyroxine, triiodothyronine and cortisol content can be characterized by the physiological state of fish, as well as the ecological state of the most water bodies.

Keywords: perch, roach, anthropogenic load, hormones, thyroxine, triiodothyronine, cortisol, glucose.

\section{PROBLEM STATEMENT AND ANALYSIS \\ OF LAST ACHIEVEMENTS AND PUBLICATIONS}

One of the reasons for the global environmental crisis, according to international experts, is the accumulation of a huge amount of production and household waste, which ultimately fall into the water bodies [1].

Most of the chemicals entering waters with wastewater and atmospheric precipitation are toxic to aquatic organisms [1-3]. Excess of some substances in the natural environment or the presence of others leads to a change in the ecological state of the water body, inevitably affects the qualitative and quantitative composition of the biota. This can be displayed on such important indicators as biodiversity and water body productivity [46]. It was also found that the effect of various toxicants on aquatic ecosystems is complex, and the role of individual components can not always be distinguished and evaluated [3]. In addition, it is known that the degree of toxicity for organisms varies throughout the year, depending on the behavior of fish and their physiological state at different times of the year. This problem is especially acute in cities where in urban conditions, in addition to industrial waste, municipal sewage discharges merge into water bodies, amounting to about $20 \%$ of the total proportion of wastewater [1].

Under such conditions, compensatory mechanisms are formed in hydrobionts in response to the action of toxicants of different nature, which is reflected, first of all, in the change in the activity of metabolic processes $[3,7]$. Therefore, there is a need to search for reliable methods for diagnosing the physiological state of fish and identify those parameters that would adequately reflect the ecological state of specific water bodies. An important role in the regulation of these processes in fish is played by the hormonal system, which, if necessary, is one of the first to trigger a chain of adaptive reactions that promote the development of stress reactions and restore the body's energy homeostasis [8-10].

\section{HIGHLIGHT OF THE EARLIER UNRESOLVED PARTS OF THE GENERAL PROBLEM. AIM OF THE STUDY}

The development of the infrastructure of the city of Kiev inevitably increases the anthropogenic pressure on water bodies, thereby worsening the ecological situation 
even in relatively safe hydroecosystems [11-12]. The quality of the aquatic environment is determined by the presence of various toxicants in the water, bottom sediments and organisms of hydrobionts. Chemical methods for measuring the amount of xenobiotics allow us to establish only their compliance with existing norms, but the real biological effect is neglected [5]. In addition, indicators of phytoplankton, macrophytes, bacterioplankton, parasitofauna and a number of others on which water quality assessment is based today, in particular within the city of Kiev, play an important role in assessing the ecological state $[6,11,13-14]$. In this regard, there is a need to develop reliable methods and criteria for the ecological assessment of water bodies, as well as toxicological control over their condition [5]. One of such criteria can be biochemical indicators of hydrobionts. In particular, this concerns indicators such as hormones of the thyroid and interrenal glands that can clarify the understanding of the processes of adaptation of fish to excessive contamination of water bodies in combination with the abiotic component [9-10, 15-16].

Based on the foregoing, the purpose of the study was to establish during the spring and summer period the physiologically-biochemical response of fish to the effect of excessive anthropogenic contamination on the indicators of the maintenance of hormones and glucose in blood plasma, and the possibility of using these indicators to assess the ecological status of the water body.

\section{MATERIALS AND METHODS}

Two Lakes in the city of Kyiv were selected for research, which are characterized by various hydrochemical and toxicological indices. These water objects were Lake Kyrylivske (Opechen Upper) - a water body from the system of Lakes Opechen (polluted by the water body) and Lake Babyne that is on Trukhanov Island (relatively clean Lake, control). Fishing was carried out in the early spring and in the middle of the summer by hook fishing gear.

The subjects of the study were perch Perca fluviatilis L. and roach Rutilus rutilus L. as species that are characteristic of these water bodies and are aboriginal. The average perch mass was $28.8 \pm 1.2 \mathrm{~g}$, body length $13.9 \pm 0.7 \mathrm{~cm}$; the average weight of the roach was $18.6 \pm 0.8 \mathrm{~g}$, and the body length was $10.5 \pm 0.7 \mathrm{~cm}$. Blood from the heart was obtained with a heparinized syringe and subsequently it was centrifuged for $15 \mathrm{~min}$ at $3000 \mathrm{rpm}$ to isolate the plasma. The blood plasma was stored at a temperature of $-18^{\circ} \mathrm{C}$.

In laboratory conditions, the total content of thyroxine (T4), triiodothyronine (T3) and cortisol in blood plasma of fish was determined by enzyme immunoassay, using commercial T3-EIA, T4-EIA sets (NPL Granum, Ukraine) and DS-EIA-SteroidCortisol («Diagnostic Systems» NGO, Russia) using the Rayto RT-2100C EIA Analyzer. The glucose content was determined by spectrophotometrically glucose oxidase method, using standard commercial kits «Filisit-Diagnostika» (Ukraine).

Statistical data was processed using the programs Statistica 10.0 and Excel programs from the Microsoft Office suite.

\section{STUDY RESULTS AND THEIR DISCUSSION}

Lake Kyrylivske (Cave II) - a water body that takes drainage of the urban drainage system. With a surface runoff from industrial sites, as well as from adjacent urban areas and roads, a large number of pollutants enter it [12-14]. The total mineralization in 


\section{PHYSIOLOGICAL-BIOCHEMICAL STATUS OF PERCH (PERCA FLUVIATILIS LINNAEUS, 1758) AND ROACH (RUTILUS RUTILUS LINNAEUS, 1758) IN CONDITIONS OF EXCESSIVE ANTHROPOGENIC PRESSURE ON THE BODY OF WATER}

April fluctuated within 520-640 mg/L, water temperature 12.5-17.2 ${ }^{\circ} \mathrm{C}$, dissolved oxygen content $6.5-10.0 \mathrm{mg} / \mathrm{L}$. In July, the mineralization was $520-573 \mathrm{mg} / \mathrm{L}$, the water temperature fluctuated within $25.6-28.2^{\circ} \mathrm{C}$, the dissolved oxygen content was 8.9-16.8 $\mathrm{mg} / \mathrm{L}$.

According to the literature, Lake Kyrylivske for indicator indicators of saprobity belongs to the category "dirty - very dirty», alpha-mesopolysaprobna, VI-VII water quality category [11]. According to the data obtained by the sanitary and epidemiological station and literature sources, the indicated water body is subject to anthropogenic load from the Kurenivka area of the city of Kiev through the collector system and the Syrets River. They are the transit waterways, which with different intensity and depending on the season of the year, the activity of industrial shops pollute the Lake with oil products, synthetic surfactants, heavy metals, pesticides, etc. [2, 12, 14]. In addition, given the great depths of the Lake, as well as the low level of water exchange, various compounds, in particular aluminum, iron, manganese, zinc and biogens accumulate in the lower soil layers $[4,17]$. These compounds are capable of entering into complexes with other substances, in particular chlorides or sulfates, thereby changing their toxic effect on hydrobionts [3].

A characteristic feature of Lake Kyrylivske is the uneven distribution of biogens between the upper and lower layers of the water body. It should be noted that in July and August, during the intensive development of blue-green and filamentous algae, the quality of water in the Lake deteriorated, which affected the dissolved oxygen content in the bottom layers of water when it decreased to $0.5-0.9 \mathrm{mg} / \mathrm{L}$.

Lake Babyne is an isolated water body, which, in fact, is not subject to anthropogenic impact through a certain distance from the city. Data on phytoplankton, macrophytes, planktonic bacteria and parasitocenosis indicate the presence of natural «virgin» complexes in the water body and high water quality $[6,11,14]$. The lake completely overgrew with surface and underwater vegetation, which, to a large extent, can indirectly determine the hydrochemical and hydrobiological regimes of the water body [13]. The total mineralization of water in April was $250 \mathrm{mg} / \mathrm{L}$, the water temperature fluctuated within $10-13^{\circ} \mathrm{C}$, the dissolved oxygen content was $8-12 \mathrm{mg} / \mathrm{L}$, in July the analogous parameters were $281.2 \mathrm{mg} / \mathrm{L}, 22.1-24.0^{\circ} \mathrm{C}, 8-11 \mathrm{mg} / \mathrm{L}$. According to indicators of saprobity, Lake water belongs to the category «clean - fairly clean», alpha-oligobeta-mesosaprobic zone, I-III category [14]. It should be noted that the concentration of a number of biogens, in particular ammonium and nitrate nitrogen in the surface and near-bottom layers of Lake water, varies within acceptable limits and does not reach significant values. Their content is characterized by a uniform distribution across the water area and depth. The insignificant content of biogens in the water body is obviously primarily associated with assimilation by producers, in particular macrophytes and phytobenthos [13].

Thyroid hormones were chosen for the study. According to a number of authors, their metabolic role is to stimulate oxidative processes and regulate lipid metabolism, form in the fish an adequate response to the entry of toxicants into the tissues of the body. Therefore, their content often assess the physiological state of fish $[10,16]$.

As a result of the research, it was found that in the spring period the content of triiodothyronine and thyroxine in the blood plasma of perch from Lake Babyne is 4.78 and 1.18 times higher, respectively, than that of the perch from Lake Kyrylivske (Figure

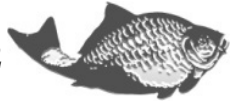


1). Increase level of $\mathrm{T} 3$ may indicate an intensification in oxidative processes in the tissues of this fish species, and its low content in perch from Lake Kyrylivske is probably caused by changes in the oxygen and temperature regime during spawning.

It can be assumed that the reduced hormonal background of the perch from Lake Kyrylivske is a consequence of an excessive anthropogenic load on this Lake in combination with fish exhaustion in the spring [19-20]. Also, this indicates a slowing of catabolic reactions in their tissues during this period. As a rule, in the spring period after wintering in fish, all metabolic mechanisms are delayed [18]. This is especially true of the processes associated with the energy supply of the fish organism. It is known that the interconversion of thyroxine and triiodothyronine, to a large extent, depends on the $\mathrm{pH}$ of the water and the ionic composition of the aqueous medium [20-21]. Considering that in the Lake the Kyrylivske values of these indicators often fluctuate as a result of anthropogenic contamination of the water area with salts of chlorides and sulphates, the content of thyroid hormones in the fish body changes proportionally.

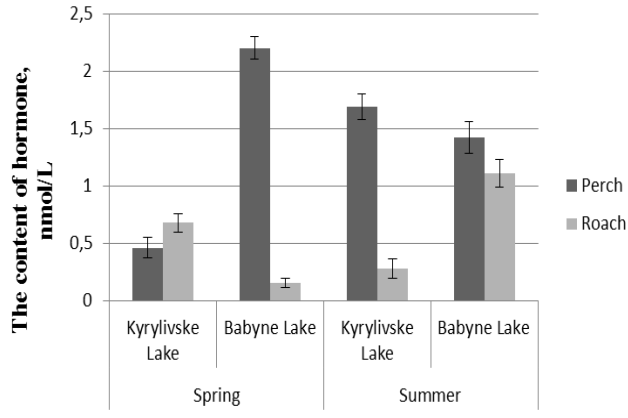

A)

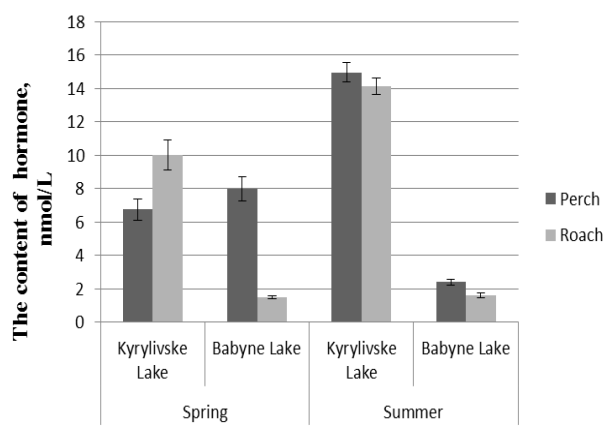

B)

Fig. 1. The content of triiodothyronine (A) and thyroxine (B) in the blood plasma of perch and roach in the spring and summer periods $(M \pm m, n=5)$

As for roach, it has a reverse reaction to the maintenance of thyroid hormones on the conditions of existence. The content of these hormones in fish from Lake Kyrylivske is significantly $(\mathrm{p} \leq 0.05)$ higher at 4.53 (T3) and 6.66 (T4) times, respectively, than in roach from Lake Babyne.

Roach for anthropogenic load proved to be more plastic than perch, and obviously actively counteracts unfavorable environment due to activation of metabolic reactions, as evidenced by increased level of thyroid hormones. The increase content of T4 can be explained by elevation water temperature, which is a limiting factor in the synthesis of this hormone [19-20]. In addition, roach, in comparison with perch, spawns later, therefore, given that the Lake Kyrylivske in this period is more warm than Babyne, the water temperature could determine the increase in the level of these hormones. Increase in plasma level of T3 in the spring before spawning can be associated with intensive maturation of gonads [15]. It is known that T4 and T3 in the body of fish can replace one another, because they perform almost identical functions. However, the active form of these hormones in tissues is T3, since it has an inherent greater affinity for hormonal receptors in tissues, than $\mathrm{T} 4[16,22]$.

In summer, the hormonal background of the fish species studied is of a different nature. The content of triiodothyronine $\mathrm{T} 3$ and thyroxine $\mathrm{T} 4$ in perch from Lake Kyrylivske, respectively, is 1.19 and 6.22 times higher, than that of the perch from Lake 
Babyne. In turn, the content of T3 in roach from the Lake of Babyne was $1.1 \mathrm{nmol} / \mathrm{L}$, which is 3.92 times higher, than in fish from Lake Kyrylivske (Fig. 1). The content of T4 in roach from Lake Kyrylivske in summer is 8.84 times higher than that of the corresponding species from Lake Babyne. The corresponding redistribution of the values of the obtained indices in the summer period can be caused by an increase in the negative impact of toxicants in the Kyrylivske Lake and a high water temperature, compared with the spring period $[1,12]$. To counteract anthropogenic factors, perch and roach include various compensatory mechanisms. Such physiological changes may be accompanied by an intensification of energy generation as a result of an increase in the activity of redox reactions, as well as by a different degree of oxygen consumption by tissues in complicated conditions of existence, in particular, enhanced by eutrophication of water $[16,21]$. It is not excluded that such a reaction may also be related to the different taxonomic status of these species, which determines the type of feeding, behavioural activity and the physiology of these fish. This, in general, can affect the nature of the redistribution of these hormones in the blood plasma. In conditions of intensive eutrophication of the water body (Lake Kyrylivske), the roach actively reduces the $\mathrm{T} 3$ content in the blood plasma.

The total content $(\mathrm{T} 3+\mathrm{T} 4)$ retains the regularities described above (Fig. 2).

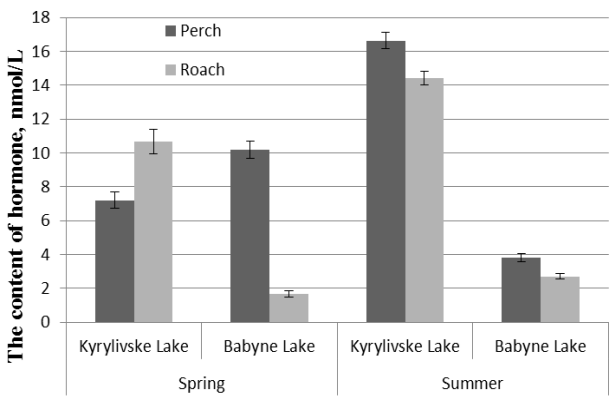

A)

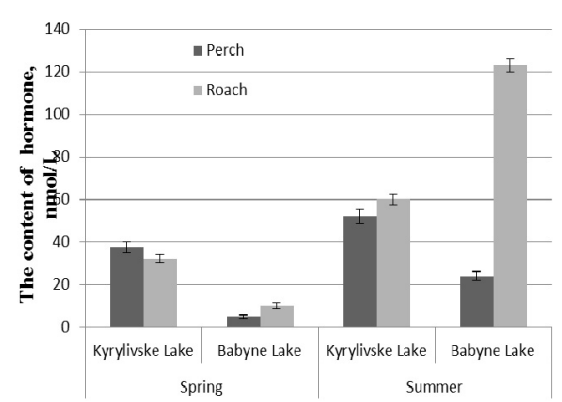

B)

Fig. 2. The total content (T3 + T4) (A) and cortisol (B) in the blood of perch and roach in the spring and summer periods $(M \pm m, n=5)$

Our research has shown that the nature of the hormonal response to the sum of the environmental factors in play is essentially dependent on the biology of a particular species $[9,19]$.

Also, we determined the content of cortisol in the blood plasma of fish under different environmental conditions of their existence. It is known that cortisol is a glucocorticosteroid that takes part in the mobilization of energy compounds, in particular glucose, lipids, fatty acids to maintain homeostasis in post-stress periods to restore energy balance $[19,23]$. It exerts a direct influence on the intermediate exchange in reactions developing in response to the occurrence of stress conditions [7-8].

Perch and roach in the spring react to the deterioration of environmental conditions by increasing the level of cortisol in the blood, namely $37.5 \mathrm{nmol} / \mathrm{L}$ and $32 \mathrm{nmol} / \mathrm{L}$ of cortisol in perch and roach from Kyrylivske, respectively, against $5 \mathrm{nmol} / \mathrm{L}$ and 10 $\mathrm{nmol} / \mathrm{L}$, respectively in the studied species from Lake Babyne (Fig. 2). This indicates that the overwhelming anthropogenic load on the water body played a predominant role in the growth of the content of this hormone in the blood plasma of fish $[12,14]$.

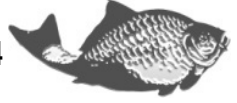


In the summer, the maintenance of cortisol in the blood of the perch in both Lakes increases proportionally in comparison with spring indicators, however, the abovementioned regularity remains. In the roach of Lake Babyne, the cortisol content in summer is 2.05 times higher than that of the corresponding species from Lake Kyrylivske, which may indicate a violation of the mobilization of energy compounds by the body of roach from Lake Kyrylivske. Obviously, the adaptation of this species to the summer conditions of existence in this Lake is more complicated than that of the perch.

The physiological state of fish for the effects of the sum of environmental factors is also appropriate to study the glucose content as the most accessible source of energy for most animals, and also a reliable indicator of stress [8].

As a result of our studies, it was found that the glucose content in the spring period perch and roach from both Lakes is almost the same (5.85-6.86 mmol/L) (Fig. 3).

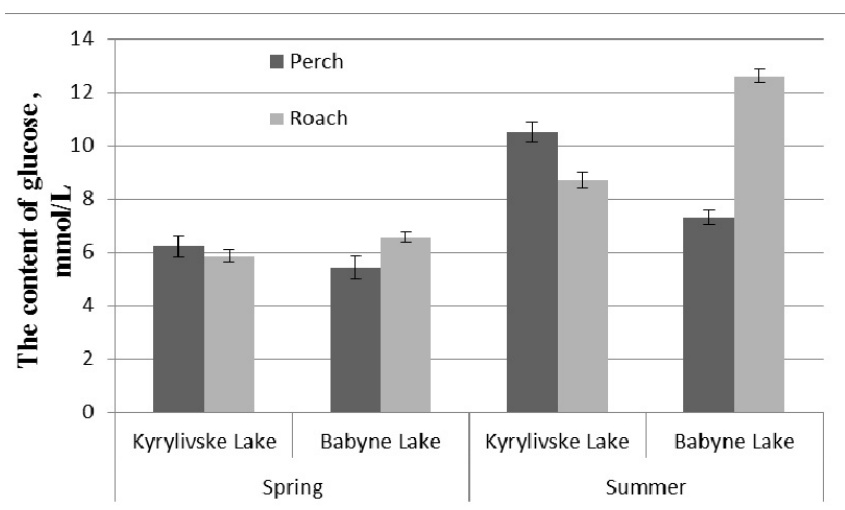

Fig. 3. The content of glucose in the blood plasma of perch and roach in the spring and summer periods $(M \pm m, n=5)$

However, in summer, the difference in the level of this indicator among fish from different water bodies was recorded. The content of glucose in the blood of perch from Lake Kyrylivske is $10.5 \mathrm{mmol} / \mathrm{L}$, which is 1.43 times higher than that of fish from Lake Babyne. In roach from the control Lake, on the contrary, the concentration of glucose in the blood plasma is 1.44 times higher than in the corresponding species from Lake Kyrylivske (Fig. 3). Again, the described changes can be related to the different taxonomic status of the investigated species [18]. Obviously, during this period the body of a perch from Kyrylivske is accumulating glucose, that is, a mechanism for counteracting toxic substances of the environment. Reduction of the energy content of the roach from the Kyrylivske Lake can be a consequence of its increased utilization to ensure the energy homeostasis of the organism under similar conditions of existence [7, 18]. In addition, the interspecies difference in glucose content may be related to various methods and intensity of its use by these fish in specific ecological conditions of life, in particular, the ionic composition of water and temperature fluctuations.

\section{CONCLUSION AND PERSPECTIVES OF FURTHER DEVELOPMENT}

In the spring, excessive anthropogenic pressure on the Lake Kyrylivske causes an energy imbalance in fish, which causes the deceleration of catabolic reactions in their tissues. In this period, the perch and roach react to the conditions of existence in the 


\section{PHYSIOLOGICAL-BIOCHEMICAL STATUS OF PERCH (PERCA FLUVIATILIS LINNAEUS, 1758) AND ROACH (RUTILUS RUTILUS LINNAEUS, 1758) IN CONDITIONS OF EXCESSIVE ANTHROPOGENIC PRESSURE ON THE BODY OF WATER}

Lake Kyrylivske increase in the content of cortisol in the blood compared with fish from the Lake. Babyne, what can be their reaction to excessive anthropogenic stress.

Also, during this period, the low content of thyroxine and triiodothyronine in the perch from the Lake Kyrylivske was noted compared with the Lake. Babyne, which is probably caused by changes in the oxygen and temperature regime during spawning.

Increase of thyroxine content in roach from Lake Kyrylivske during the summer period with respect to fish from the Lake Babyne may indicate an increase in the negative effects of toxic substances on the physiological state of fish as water temperature rises. At the perch from the Lake Kyrylivske content of T3 and T4 in 1.19 and 6.22 times, respectively is higher, than that of fish from the Lake Babyne, which is associated with enhanced processes of generating energy in his body, as a result of increased activity of redox reactions, as well as different degrees of oxygen consumption by tissues under complicated conditions of existence.

In the summer, in the roach from the Lake Babyne content of cortisol is 2.05 times higher than that of roach of Lake Kyrylivske, which may be the result of a violation of the mobilization of energy compounds by the organism of this species from the Lake Kyrylivske The content of glucose in the blood plasma of the perch from the Lake Kyrylivske was $10.5 \mathrm{mmol} / \mathrm{L}$ in the summer, which is 1.43 times higher than that of fish from the Lake Babyne. Such a buildup of glucose can be a mechanism for counteracting toxic substances in the environment. Decrease of glucose content in roach from Lake Kyrylivske is probably the consequence of increased its utilization to ensure the energy homeostasis of the organism under similar conditions of existence.

The obtained results of the content of hormones allow monitoring the Lakes of the megapolis to assess the physiological state of the background representatives of the ichthyofauna, in particular perch and roach, and to assess the ecological state of the most water bodies.

\section{BIBLIOGRAPHY}

1. Білявський Г. О., Фурдуй Р. С., Костіков І. Ю. Основи екології. Київ : Либідь, 2005. $408 \mathrm{c}$.

2. Акімова О. Р., Кураєва I. В., Злобіна К. С. Літологічна характеристика і геохімічний розподіл важких металів у поверхневих водах і донних відкладах Київського мегаполісу // Екологія і природокористування. 2013. Вип. 17. С. 98-104.

3. Сергеева Н. Р., Лукьяненко В. И. Общая ихтиотоксикология. Краснодар : Наука, 2008. 157 с.

4. Гідрохімічний режим озер системи Опечень (м. Київ) / Линник П. М. та ін. // Наукові праці Українського науково-дослідного гідрометеорологічного інституту. 2016. Вип. 269. С. 59-69.

5. Рощина О. В. Влияние природних и антропогенных факторов на активность ферментов сыворотки крови черноморских рыб (на примере морского ерша): автореф. дис. на соискание уч. степени канд. биол. наук : спец. 03.00.16 «Экология». Москва, 2010. 23 с.

6. Щербак В. I., Семенюк Н. С. Функціональна характеристика фітопланктону водойм мегаполісу // Наукові записки Терноп. нац. пед. ун-ту ім. В. Гнатюка. 2010. № 2 (43). С. 556-559. (Серія : Біологія). 
7. Cortisol response and immunerelated effects of Atlantic Salmon (Salmo salar Linnaeus) subjected to short- and long-term stress / Fast M. D. et al. // Fish and Shellfish Immunol. 2008. Vol. 24. P. 194-204.

8. Martínez-Porchas M., Martínez-Córdova L. R., Ramos-Enriquez R. Cortisol and Glucose: Reliable indicators of fish stress? // Pan-American Journal of Aquatic Sciences. 2009. Vol. 4, № 2. P. 158-178.

9. Prychepa M. V., Potrokhov O. S. Hormonal regulation of adaptative processes in fishes to impact of abiotic factors // Hydrobiol. J. 2016. Vol. 52, № 1. P. 86-98.

10. Oliveira M., Pacheco M., Santos M. A. Fish thyroidal and stress responses in contamination monitoring — an integrated biomarker approach // Ecotoxicol. Environ. Sci. 2011.Vol. 74. № 5. P. 1265-1270.

11. Юришинець В. I. Структура симбіоценозу гідробіонтів як показник екологічного стану водних об'єктів урбанізованих територій // Наук. зап. Терноп. нац. пед. ун-ту ім. В. Гнатюка. 2015. № 3-4 (64). С. 764-767. (Серія : Біологія).

12. Якість води у міських водоймах та характер освоєння водоохоронних зон (на прикладі озер системи «Опечень», м. Київ) / Панасюк І. В. та ін. // Екологічна безпека та природокористування. 2015. № 4(20). С. 63-69.

13. Гідрохімічна та мікробіологічна характеристика оз. Бабиного, розташованого в межах м. Києва / Якушин В. М. та ін. // Наук. зап. Терноп. нац. пед. ун-ту ім. В. Гнатюка. 2015. № 3-4 (64). С. 776-779. (Серія : Біологія).

14. Екологічні проблеми київських водойм і прилеглих територій / Романенко О. В. та ін. Київ : Наукова думка, 2015. 189 с.

15. Болотовский А. А., Левин В. А. Сезонная изменчивость уровня трийодтиронина у трех видов карповых рыб из Рыбинского водохранилища, бассейн Волги // Всерос. конф. с междунар. участием, 12 сент. 2012 г. : тезисы докл. Борок, 2012. С. 54-57.

16. Metabolic and thyroidal response in air-breating perch (Anubus testudineus) to water-borne kerosene / Peter V. S. et al // Gen. Comp. Endocrinol. 2007. Vol. 152. P. 198-205.

17. Сучасна гідроекологія: місце наукових досліджень у вирішенні актуальних проблем / Жежеря В. А. та ін.// III наук.-практ. конф. для молодих вчених, 6-7 жовт. 2016 р. : тези доп. Київ, 2016. С. 20-23.

18. Ананьева Т. В., Федоненко О. В. Біохімічні показники тканин і органів окуня (Perca fluviatilis L.) Запорізького водосховища // Питання біоіндикації та екології. 2010. Вип. 15, № 2. С. 223-231.

19. Потрохов О. С., Зіньковський О. Г., Худіяш Ю. М. Гормональний статус окуня та плітки за зміни екологічних чинників водного середовища // Наук. записки Терноп. нац. пед. ун-ту ім. В. Гнатюка. 2015. № 3-4. С. 539-543. (Серія : Біологія).

20. Little A. G. Thyroid hormone actions are temperature-specific and regulate thermal acclimation in zebrafish (Danio rerio) // BMC Biology. 2013. P. 15.

21. Farbridge K. J., Leatherland J. F. Temporal changes in plasma thyroid hormone, growth hormone and free fatty acid concentrations, and hepatic 5'-monodeiodinase activity, lipid and protein content during chronic fasting and refeeding in rainbow trout (Oncorhynchus mykiss) // Fish Physiol. Biochem. 1992. Vol. 10. P. 245-257.

22. Effects of cortisol and thyroid hormone on peripheral outer ring deiodination and osmoregulatory parameters in the Senegalese sole (Solea senegalensis) / Arjona F. J. et al // Journal of endocrinology. 2011. Vol. 208. P. 323-330. 


\section{PHYSIOLOGICAL-BIOCHEMICAL STATUS OF PERCH (PERCA FLUVIATILIS LINNAEUS, 1758) AND ROACH (RUTILUS RUTILUS LINNAEUS, 1758) IN CONDITIONS OF EXCESSIVE ANTHROPOGENIC PRESSURE ON THE BODY OF WATER}

23. Hopkins T. E.,Wood C. D.,Walsh P. J. Interactions of cortisol and nitrogen metabolism in the ureogenic gulf toadfish Opsanus beta // J. Exper.Biol. 1995. Vol. 198. P. 2229-2235.

\section{REFERENCES}

1. Bilyavs'kyy, H. O., Furduy, R. S., \& Kostikov, I. Yu. (2005). Osnovy ekolohiyi. Kyiv: Lybid'.

2. Akimova, O. R. (2013). Litolohichna kharakterystyka i heokhimichnyy rozpodil vazhkykh metaliv u poverkhnevykh vodakh i donnykh vidkladakh Kyyivs'koho mehapolisu. Ekolohiya i pryrodokorystuvannya, 17, 98-104.

3. Sergeeva, N. R., \& Luk'janenko, V. I. (2008). Obshhaja ihtiotoksikologija. Krasnodar: Nauka.

4. Lynnyk, P. M., Zhezherya, V. A., \& Zhezherya, T. P. et al. (2016). Hidrokhimichnyy rezhym ozer systemy Opechen' (m. Kyyiv). Naukovi pratsi Ukrayins'koho naukovo-doslidnoho hidrometeorolohichnoho instytutu, 269, 59-69.

5. Roshhina, O. V. (2010). Vlijanie prirodnih i antropogennyh faktorov na aktivnost' fermentov syvorotki krovi chernomorskih ryb (na primere morskogo ersha). Extended abstract of candidate's thesis. Moskva.

6. Shcherbak, V. I., \& Semenyuk, N. Ye. (2010). Funktsional'na kharakterystyka fitoplanktonu vodoym mehapolisu. Naukovi zapysky Ternop. natsped. u-tu im. V. Hnatyuka. Seriia Biolohiya, 2(43), 556-559.

7. Fast, M. D., Hosoya, S., \& Johnson, S. C. et al. (2008). Cortisol response and immunerelated effects of Atlantic Salmon (Salmo salar Linnaeus) subjected to short- and long-term stress. Fish and Shellfish Immunol., 24, 194-204.

8. Martínez-Porchas, M., Martínez-Córdova, L. R., \& Ramos-Enriquez, R. (2009). Cortisol and Glucose: Reliable indicators of fish stress. Pan-American Journal of Aquatic Sciences, 4, 158-178.

9. Prychepa, M. V., \& Potrokhov, O. S. (2016). Hormonal regulation of adaptative processes in fishes to impact of abiotic factors. Hydrobiol. J., 52, 1, 86-98.

10. Oliveira, M., Pacheco, M., \& Santos, M. A. (2011). Fish thyroidal and stress responses in contamination monitoring - an integrated biomarker approach. Ecotoxicol. Environ. Sci., 74, 1265-1270.

11. Yuryshynets', V. I. (2015). Struktura symbiotsenozu hidrobiontiv yak pokaznyk ekolohichnoho stanu vodnykh ob"yektiv urbanizovanykh terytoriy. Naukovi zapysky Ternop. natsped. u-tu im. V. Hnatyuka. Seriia Biolohiya, 3-4(64), 764-767.

12. Panasyuk, I. V., Tomil'tseva, A. I., Zub, L. M., \& Pohoryelova, Yu.V. (2015). Yakist' vody u mis'kykh vodoymakh ta kharakter osvoyennya vodookhoronnykh zon (na prykladi ozer systemy «Opechen'», m. Kyyiv). Ekolohichna bezpeka ta pryrodokorystuvannya, 4(20), 63-69.

13. Yakushyn, V. M., Romanyshyn, H. M., Kalenichenko, K. P., \& Linchuk, M. I. (2015). Hidrokhimichna ta mikrobiolohichna kharakterystyka oz. Babynoho, roztashovanoho v mezhakh m. Kyyevai. Naukovi zapysky Ternop. natsped. u-tu im. V. Hnatyuka. Seriia Biolohiya, 3-4(64), 776-779.

14. Romanenko, O. V., Arsan, O. M., Kipnis, L. S., \& Sytnyk, Yu. M. (2015). Ekolohichni problemy kyyivs'kykh vodoym i prylehlykh terytoriy. Kyyiv: Naukova dumka.

15. Bolotovskyy, A. A. (2012). Sezonnaja izmenchivost' urovnja trijodtironina u treh 
vidov karpovyh ryb iz Rybinskogo vodohranilishha, bassejn Volgi. Vserossijskaja konferenciia s mezhdunarodnym uchastiem: materialy. Borok, 54-57.

16. Peter, V. S., Joskua, E. K., Wendelaar-Bonga, S. E., \& Peter, M. C. S. (2007). Metabolic and thyroidal response in air-breating perch (Anubus testudineus) to water-borne kerosene. Gen. Comp. Endocrinol, 152, 198-205.

17. Zhezherya, V. A., Zadorozhna, H. M., Batoh, S. V., \& Zhezherya, T. P. (2016). Suchasna hidroekolohiya: mistse naukovykh doslidzhen' u vyrishenni aktual'nykh problem. III naukovo-prakt. konf. dlya molodykh vchenykh: zb. materialiv. Kyyiv, 20-23.

18. Anan'eva, T. V. (2010). Biokhimichni pokaznyky tkanyn i orhaniv okunya (Perca fluviatilis L.) Zaporiz'koho vodoskhovyshcha. Pytannya bioindykatsiyi ta ekolohiyi, 15, 223-231.

19. Potrokhov, O. S., Zin'kovs'kyy, O. H., \& Khudiyash, Yu. M. (2015). Hormonal'nyy status okunya ta plitky za zminy ekolohichnykh chynnykiv vodnoho seredovyshcha. Naukovi zapysky Ternop. natsped. u-tu im. V. Hnatyuka. Seriia Biolohiya, 3-4(64), 539-543.

20. Little, A. G. (2013). Thyroid hormone actions are temperature-specific and regulate thermal acclimation in zebrafish (Danio rerio). BMC Biology, 15.

21. Farbridge, K. J., \& Leatherland, J. F. (1992). Temporal changes in plasma thyroid hormone, growth hormone and free fatty acid concentrations, and hepatic 5'monodeiodinase activity, lipid and protein content during chronic fasting and refeeding in rainbow trout (Oncorhynchus mykiss). Fish Physiol. Biochem., 10, 245-257.

22. Arjona, F. J., Vargas-Chacoff, L., \& Martin del Rio, M. P. et al. (2011). Effects of cortisol and thyroid hormone on peripheral outer ring deiodination and osmoregulatory parameters in the Senegalese sole (Solea senegalensis). Journal of endocrinology, 208, 323-330.

23. Hopkins, T. E., Wood, C. D., \& Walsh, P. J. (1995). Interactions of cortisol and nitrogen metabolism in the ureogenic gulf toadfish Opsanus beta. J. Exper. Biol., 198, 2229-2235.

\section{ФІЗІОЛОГО-БІОХІМІЧНИЙ СТАТУС ОКУНЯ РІЧКОВОГО (РЕRCA FLUVIATILIS LINNAEUS, 1758) ТА ПЛІТКИ ЗВИЧАЙНОÏ (RUTILUS RUTILUS LINNAEUS, 1758) В УМОВАХ НАДМІРНОГО АНТРОПОГЕННОГО НАВАНТАЖЕННЯ НА ВОДОЙМУ}

В. М. Марценюк, wmarzenuk@gmail.com, Інститут гідробіології НАН України, м. Київ

О. С. Потрохов, alport@bigmir.net, Інститут гідробіології НАН України, м. Київ

О. Г. Зіньковський, oleg-zinkovskiy@rambler.ru, Інститут гідробіології НАН України, м. Київ

М. В. Причепа, prichepa1987@ukr.net, Інститут гідробіології НАН України, м. Київ

Мета. Встановити у весняний та літній періоди фізіолого-біохімічну відповідь риб на вплив надмірного антропогенного забруднення за показниками вмісту гормонів та глюкози в їх плазмі крові, та можливість використання цих показників для оцінки екологічного стану водойми.

Методика. Для дослідження було обрано два озера м. Києва, які характеризуються різними гідрохімічними та токсикологічними показниками. Цими водоймами були оз. Кирилівське (Опечень Верхнє) - водойма із системи озер Опечень (забруднена водойма) та озеро Бабине, що знаходиться на Трухановому острові (відносно чисте озеро, контроль). Ловлю риб здійснювали ранньою весною та в середині літа гачковими знаряддями лову. у 
лабораторних умовах визначали загальний вміст тироксину (T4), трийодтироніну (Т3) та кортизолу у плазмі крові риб імуноферментним методом, використовуючи комерційні набори ТЗ-ІФА, Т4-ІФА (НВЛ «Гранум», Україна) та "ДС-ІФА-Стероїд-Кортизол» (НВО "Діагностичні системи», Росія) за допомогою (ФА-аналізатора "Rayto RT-2100C». Bмicm глюкози встановлювали спектрофотометрично глюкозооксидазним методом 3 використанням стандартних комерційних наборів «Філісіт-Діагностика» (Україна).

Cтатистичну обробку даних проводили з використанням програм Statistica $10.0 \mathrm{ma}$ програми «Excel» із пакету «Microsoft Office».

Результати. У весняний період надмірне антропогенне навантаження на оз. Кирилівське викликає енергетичний дисбаланс у риб, який зумовлює сповільнення катаболічних реакцій в їхніх тканинах. У цей період окунь та плітка реагують на умови існування в оз. Кирилівьке підвищенням вмісту кортизолу у крові, порівняно з рибами із оз. Бабине, що може бути їх реакцією на надмірне антропогенне навантаження.

Також, в цей період було відмічено нижчий вміст тироксину та трийодтироніну в окуня із оз. Кирилівське порівняно із оз. Бабине, що, ймовірно, спричинене перепадами кисневого та температурного режиму у періоди нересту.

Підвищення вмісту тироксину у плітки із оз. Кирилівське у літній період відносно риб із оз. Бабине, може свідчити про подсилення негативної дії токсичних речовин на фізіологічний стан риб у міру зростання температури води. У окуня ж із оз. Кирилівське вміст Т3 та Т4 у 1,19 та 6,22 раза відповідно вищий, ніж у риб із оз. Бабине, що пов'язано із посиленням процесів генеруванням енергії в його організмі, внаслідок підвищення активності окисно-відновних реакцій, а також із різним ступенем споживання кисню тканинами за ускладнених умов існування.

Влітку ж у плітки із оз. Бабине вміст кортизолу в 2,05 раза вищий, ніж такої із оз. Кирилівське, що може бути наслідком порушення мобілізації енергетичних сполук організмом цього виду із оз. Кирилівське. Вміст глюкози у плазмі крові окуня із оз. Кирилівське влітку становив 10,5 ммоль/л, що у 1,43 раза вище, ніж у риб із оз. Бабине. Подібне накопичення глюкози може бути механізмом протидії токсичним речовинам навколишнього середовища. Зниження вмісту глюкози в плітки із оз. Кирилівське, ймовірно, є наслідком підвищеної утилізації чієї сполуки для забезпечення енергетичного гомеостазу організму за подібних умов існування.

Наукова новизна. Встановлено міжвидову та міжсезонну різницю за вмістом гормонів у окуня та плітки, які перебували під впливом антропогенного навантаження на водойми мегаполісу.

Практична значимість. Отримані результати дозволяють стверджувати, що за показниками вмісту тироксину, трийодтироніну та кортизолу можна характеризувати фізіологічний стан риб, а також очінити екологічний стан самих водойм.

Ключові слова: окунь, плітка, антропогенне навантаження, гормони, тироксин, трийодтиронін, кортизол, глюкоза.

\title{
ФИЗИОЛОГО-БИОХИМИЧЕСКИЙ СТАТУС ОКУНЯ РЕЧНОГО (PERCA FLUVIATILIS LINNAEUS, 1758) И ПЛОТВЫ ОБЫКНОВЕННОЙ (RUTILUS RUTILUS LINNAEUS, 1758) В УСЛОВИЯХ ЧРЕЗМЕРНОЙ АНТРОПОГЕННОЙ НАГРУЗКИ НА ВОДОЕМ
}

\author{
В. Н. Марценюк, wmarzenuk@gmail.com, Институт гидробиологии НАН Украины, \\ г. Киев \\ А. С. Потрохов, alport@bigmir.net, Институт гидробиологии НАН Украины, г. Киев \\ О. Г. Зиньковський, oleg-zinkovskiy@rambler.ru, Институт гидробиологии НАН \\ Украины, г. Киев
}

Н. В. Причепа, prichepa1987@ukr.net, Институт гидробиологии НАН Украины, г. Киев

Цель. Установить в весенний и летний периоды физиолого-биохимический ответ рыб на воздействие чрезмерного антропогенного загрязнения по показателям содержания 
гормонов и глюкозы в их плазме крови, и возможность использования этих показателей для оценки экологического состояния водоема.

Методика. Для исследования были выбраны два озера г. Киева, которые характеризуются различными гидрохимическими и токсикологическими показателями. Этими водоемами были оз. Кирилловское (Опечень Верхнее) - водоем из системы озер Опечень (загрязненный водоем), и оз. Бабье, находящееся на Трухановом острове (относительно чистое озеро, контроль). Ловлю рыб осуществляли ранней весной и в середине лета крючковыми орудиями лова. В лабораторных условиях определяли общее содержание тироксина (Т4), трийодтиронина (Т3) и кортизола в плазме крови рыб иммуноферментным методом, используя коммерческие наборы ТЗ-ИФА, Т4-ИФА (НПЛ «Гранум», Украина) и "ДС-ИФА-Стероид-Кортизол» (НПО "Диагностические системы», Россия) с помощью ИФА-анализатора «Rayto RT-2100C». Содержание глюкозы устанавливали спектрофотометрически глюкозооксидазным методом с использованием стандартных коммерческих наборов «Филисит-Диагностика» (Украина).

Статистическую обработку данных проводили с использованием программ «Statistica 10.0» и «Excel» пакета "Microsoft Office».

Результаты. В весенний период чрезмерная антропогенная нагрузка на оз. Кирилловское вызывает энергетический дисбаланс у рыб, обуславливающий замедление катаболических реакций в их тканях. В этот период окунь и плотва реагируют на условия существования в оз. Кирилловское повышением содержания кортизола в крови по сравнению с рыбами оз. Бабье, что может быть их реакцией на чрезмерную антропогенную нагрузку.

Также, в этот период было отмечено низкое содержание тироксина $u$ трийодтиронина у окуня из оз. Кирилловское по сравнению с оз. Бабье, что, вероятно, вызвано перепадами кислородного и температурного режима в периоды нереста.

Повышение содержания тироксина у плотвы из оз. Кирилловское в летний период относительно рыб из оз. Бабье может свидетельствовать об усилении негативного воздействия токсичных веществ на физиологическое состояние рыб по мере роста температуры воды. У окуня же из оз. Кирилловское содержание ТЗ и Т4 в 1,19 и 6,22 раза соответственно выше, чем у рыб из оз. Бабье, что связано с усилением процессов генерирования энергии в его организме, вследствие повышения активности окислительновосстановительных реакций, а также с различной степенью потребления кислорода тканями в осложненных условиях существования.

Летом же у плотвы из оз. Бабье содержание кортизола оказалось в 2,05 раза выше, чем у плотвы из оз. Кирилловское, что может быть следствием нарушения мобилизации энергетических соединений организмом этого вида из оз. Кирилловское. Содержание глюкозы в плазме крови окуня из оз. Кирилловское летом составлял 10,5 ммоль/дм, что в 1,43 раза выше, чем у рыб из оз. Бабье. Подобное накопление глюкозы может быть механизмом противодействия токсичным веществам окружающей среды. Снижение содержания глюкозы у плотвы из оз. Кирилловское, вероятно, является следствием повышенной утилизации этого соединения для обеспечения энергетического гомеостаза организма при подобных условиях существования.

Научная новизна. Установлена межвидовая и межсезонная разница в содержании гормонов у окуня и плотвы, которые находились под влиянием антропогенной нагрузки на водоемы мегаполиса.

Практическая значимость. Полученные результаты позволяют утверждать, что по показателям содержания тироксина, трийодтиронина и кортизола можно характеризовать физиологическое состояние рыб, а также оценить экологическое состояние самих водоемов.

Ключевые слова: окунь, плотва, антропогенная нагрузка, гормоны, тироксин, трийодтиронин, кортизол, глюкоза. 